Article

\title{
Nitrite Stress Induces Oxidative Stress and Leads to Muscle Quality Decreased in Wuchang Bream (Megalobrama amblycephala Yih) Juveniles
}

\author{
Zhenyi Hu ${ }^{1} \mathbb{D}$, Chenglong Qi ${ }^{1}$, Chenzhi Lin ${ }^{1}$ and Rong Tang ${ }^{2, *(\mathbb{D})}$
}

1 Hubei Provincial Engineering Laboratory for Pond Aquaculture, Engineering Research Center of Green Development for Conventional Aquatic Biological Industry in the Yangtze River Economic Belt, College of Fisheries, Huazhong Agricultural University, Ministry of Education, Wuhan 430070, China; zhenyihu@webmail.hzau.edu.cn (Z.H.); Kenton.Qi@kraftheinz.com (C.Q.); linchenzhi2022@163.com (C.L.)

2 Key Laboratory of Freshwater Animal Breeding, Freshwater Aquaculture Collaborative Innovation Center of Hubei Province, College of Fisheries, Huazhong Agricultural University, Ministry of Agriculture, No. 1 Shizishan Street Hongshan District, Wuhan 430070, China

* Correspondence: tangrong@mail.hzau.edu.cn; Tel.: +86-27-8728-2113; Fax: +86-27-8728-2114

Citation: Hu, Z.; Qi, C.; Lin, C.; Tang, R. Nitrite Stress Induces Oxidative Stress and Leads to Muscle Quality Decreased in Wuchang Bream (Megalobrama amblycephala Yih) Juveniles. Water 2022, 14, 160. https://doi.org/10.3390/w14020160 Academic Editor: José Luis Sánchez-Lizaso

Received: 15 November 2021

Accepted: 5 January 2022

Published: 8 January 2022

Publisher's Note: MDPI stays neutral with regard to jurisdictional claims in published maps and institutional affiliations.

Copyright: (C) 2022 by the authors. Licensee MDPI, Basel, Switzerland. This article is an open access article distributed under the terms and conditions of the Creative Commons Attribution (CC BY) license (https:/ / creativecommons.org/licenses/by/ $4.0 /)$.

\begin{abstract}
To determine the effects of nitrite exposure on muscle quality and physiological functions in Wuchang bream (Megalobrama amblycephala), we exposed M. amblycephala juveniles to acute nitrite $(0,1,5,10,20 \mathrm{mg} / \mathrm{L})$, and the muscle and blood samples were measured at 12, 24, 48, and $96 \mathrm{~h}$. The results showed that when exposed to nitrite for $12 \mathrm{~h}$, the concentrations of blood glucose, cortisol, aspartate aminotransferase (AST), and alanine aminotransferase (ALT) in the $20 \mathrm{mg} / \mathrm{L}$ experimental group had the maximum value. The activity of lactate dehydrogenase (LDH) increased significantly in a dose-dependently manner and peaked at $96 \mathrm{~h}$ in the $20 \mathrm{mg} / \mathrm{L}$ group. During $96 \mathrm{~h}$ of exposure to nitrite, the total antioxidant capacity (T-AOC) and catalase (CAT) activity in the liver of the $20 \mathrm{mg} / \mathrm{L}$ experimental group were significantly higher than those of the control group, while the concentration of muscle glycogen showed a downtrend. At $12 \mathrm{~h}$ and $96 \mathrm{~h}$, the hardness of the four experimental groups were significantly higher than that of the control group. Our research shows that acute sodium nitrite exposure will not only cause oxidative stress and decreased muscle quality in M. amblycephala juveniles but also will be accompanied by changes in serum biochemical index, liver antioxidant capacity, muscle physiological characteristics, and muscle physical characteristics. Preliminary speculation may be that acute nitrite exposure may cause M. amblycephala juveniles to choose to reduce muscle quality and activate antioxidant systems.
\end{abstract}

Keywords: Wuchang bream (M. amblycephala); nitrite; antioxidant; muscle quality

\section{Introduction}

With the increase in total production, the aquaculture industry pays more and more attention to muscle quality. Moreover, the body's metabolism is usually closely related to muscle quality. In order to maintain the homeostasis in fish and resist stress, it always requires a lot of energy consumption. Therefore, a large amount of metabolic waste is accumulated. High levels of nitrite exposure cause considerable stress in fish, and its toxicity manifests in physiological change, tissue damage, and cell injury [1]. It was reported that the increase in glucose, glycogenolysis, and lactate is caused by increased energy demand and anaerobic metabolism under tissue hypoxia caused by exposure to nitrite [2] Glucose is important because glucose concentrations are generally elevated by the increase in carbohydrate metabolism of fish exposed to toxic substances [3]. The utilization of glucose and glycogen by aquatic animals is a mechanism for detoxification, and glucose concentrations generally increase under stressful conditions [4]. Simultaneously, detoxification of nitrite occurs via endogenous oxidation to nitrate and inhibiting the activity 
of antioxidant enzymes system [5]. This may result in a negative impact on fish muscle texture characteristics.

Nitrite $\left(\mathrm{NO}^{2-}\right)$ is found in ecosystems as a natural component of the nitrogen cycle [5] and is potentially dangerous in the environment [6]. Nitrite is a common pollutant in aquaculture water. Excessive accumulation of nitrite can cause oxidative stress and is toxic to fish [7]. In fish farming systems, the concentration of $\mathrm{NO}^{2-}$ is usually low, but due to the high stocking density of fish or the addition of fertilizers to the water, there may be an imbalance between bacterial nitrification and denitrification, which will eventually lead to the accumulation of nitrite [8,9]. The high level of nitrite may affect the physiological functions of aquatic animals, including ion regulation, cardiovascular, respiration, endocrine and excrement, and even damage the health of fish, resulting in a large number of deaths [5,10-12].The toxicity mechanism and physiological effects of nitrite have been extensively studied in many fishes and fish cells [13-15].

Living organisms produce a certain amount of reactive oxygen species (ROS) during normal growth. Due to the role of the antioxidant system, the body can eliminate these oxygen free radicals through its own ability. Common antioxidant systems are mainly composed of superoxide dismutase (SOD), glutathione peroxidase (GPx), and catalase (CAT). Fish, especially freshwater fish, exposed to high levels of nitrite may cause the accumulation of nitrite in various tissues of the fish body, affecting the plasma components [16]. Stress enhancement, tissue hypoxia, and the accumulation of oxygen free radicals in the body inhibit the antioxidant system, directly or indirectly affecting the immune vitality of fish [17]. Eventually it will damage the health of the fish and even cause death. Experiments have shown that nitrite stress can induce endoplasmic reticulum stress and calcium ion disturbance in fish hepatocytes [18]. Hematological parameters are considered reliable indicators of the physiology and health status of fish exposed to toxic substances $[4,19]$. The blood is a major target site of nitrite action in fish exposed to waterborne nitrite [11]. Nitrite enters the plasma through chloride cells in fish gills [20]. Thus, hematological parameters and plasma components are critical factors in assessing toxic effects of nitrite exposure in fish [15].

As an important freshwater fish in China, M. amblycephala is a widely accepted food fish. The aquaculture industry of this fish has spread all over the country. In the past decade, large-scale aquaculture has developed rapidly because this species is very suitable for intensive aquaculture using natural foods, but it is vulnerable to environmental factors [21]. Previous studies have investigated the physiological response of fish to acute nitrite exposure [22-24]. In addition, there are few studies on the effects of acute exposure to sodium nitrite stress on fish muscle quality. We used the method of acute toxicity test. M. amblycephala juveniles were exposed to sodium nitrite aqueous solution at different concentrations and at different times. Therefore, this study was aimed to comprehensive analysis the antioxidant index and muscle quality after acute exposure to sodium nitrite in M. amblycephala juveniles, as well as to investigate the effects of acute toxicity on serum biochemical index, liver antioxidant capacity, muscle physiological characteristics, and muscle physical characteristics.

\section{Materials and Methods}

\subsection{Experimental Fish and Rearing Conditions}

M. amblycephala juveniles were obtained from the Fish Hatchery of Tuanfeng (Hubei province of China). Prior to the experiment, they were transferred to the aquatic laboratory holding tanks, which had a radius of $42 \mathrm{~cm}$ and height of $60 \mathrm{~cm}$. The fish were fed with a commercial pelleted diet twice daily at a ration of $4 \%$ body weights. Ammonia and nitrate levels were less than $0.1 \mathrm{mg} / \mathrm{L}, \mathrm{pH} 7.3 \pm 0.2$, a water temperature of $20 \pm 3{ }^{\circ} \mathrm{C}$; dissolved oxygen was $7.0 \pm 0.5 \mathrm{mg} / \mathrm{L}$ during the holding period. One-third of the water was changed every 2 days to ensure good water quality. 


\subsection{Nitrite Exposure and Sample Collection}

Having been acclimatized for 2 weeks, the fish (average weight $213 \pm 33 \mathrm{~g}$ ) were randomly selected for the $96 \mathrm{~h}$ acute toxicity test. Sodium nitrite solutions of different concentrations were used as the nitrite stress solution. A $96 \mathrm{~h}$ nitrite exposure was used at five sodium nitrite levels: $0 \mathrm{mg} / \mathrm{L}$ (control), $1 \mathrm{mg} / \mathrm{L}, 5 \mathrm{mg} / \mathrm{L}, 10 \mathrm{mg} / \mathrm{L}$, and $20 \mathrm{mg} / \mathrm{L}$ in triplicate ( 25 individuals per tank). Each ambient nitrite concentration of experimental groups was measured every $4 \mathrm{~h}$ and adjusted to the relative constant value by adding sodium nitrite to the tank. The sodium nitrite was purchased from Sinopharm Chemical Reagent Co., Ltd. (Shanghai, China), with a purity greater than or equal to $99.0 \%$.

Each group of nine-tailed fish was randomly selected and anesthetized with MS-222 (MedChemExpress, Monmouth Junction, NJ, USA). The sample was collected at $12 \mathrm{~h}, 24 \mathrm{~h}$, $48 \mathrm{~h}$, and $96 \mathrm{~h}$ during the nitrite exposure. A $1 \mathrm{~mL}$ syringe was used to take blood from the tail artery of the experimental fish. Serum was separated by centrifugation at $3500 \mathrm{r} / \mathrm{min}$ for $30 \mathrm{~min}$. The serum was stored at $-80^{\circ} \mathrm{C}$. Serum was used for the detection of biochemical indicators. We used sterile surgical instruments to collect experimental fish tissues. Liquid nitrogen was used to preserve experimental tissues. The experimental tissue samples were used for anti-oxidation index detection. A fresh steak of $1 \mathrm{~cm}$ thickness muscle between the dorsal and caudal fin was sampled for measuring of texture parameters. A total of $10 \mathrm{~g}$ muscle lateral line was frozen at $-80{ }^{\circ} \mathrm{C}$ for determination of lactic acid and glycogen.

\subsection{Oxidative Stress Biomarkers}

\subsubsection{Physiological and Biochemical Indicators}

Lactate dehydrogenase (LDH) was determined by NAD-UV method, total cholesterol was calculated with the COD-POD method, blood glucose was calculated with the hexokinase method, triglyceride was calculated with the endpoint method, total protein was calculated with the biuret method, alanine aminotransferase (ALT) was calculated with the LDH-UV method, and aspartate aminotransferase (AST) was calculated with the MDHUV method; automatic biochemical analysis was performed in a Chemix-800 automatic biochemical analyzer (Sysmex Corporation, Kobe, Japan). Measured on the analyzer, the kits were purchased from Wuhan Kangruijia Technology Co., Ltd. (Wuhan, China). The cortisol was determined by radioimmunoassay (RIA), and the kit was purchased from Beijing Northern Institute of Biotechnology (Beijing, China). Glycogen was determined by oxidation colorimetric method, and the kit used was purchased from Nanjing Jiancheng Biochemical Corporation (Nanjing, China).

\subsubsection{Antioxidant Capacity}

The antioxidant capacity of the liver was measured by the supernatant after homogenizing, and the total antioxidant capacity (T-AOC) was measured by the iron reduction method. The activity of antioxidant enzymes such as superoxide dismutase (SOD) was determined by the xanthine oxidase method. The activity of catalase (CAT) and glutathione peroxidase (GPx) were determined by the oxidation reaction. The kit used was purchased from Nanjing Jiancheng Biochemical Corporation (Nanjing, China).

\subsection{Determination of Related Indices of Muscle Metabolism}

\subsubsection{Metabolism Analysis}

The detection of muscle glycogen and lactic acid were determined by colorimetric method (Infinite M200 Nanoquant, Tecan, Männedorf, Switzerland). Glycogen was dehydrated by $98 \%$ sulfate and reacted with anthrone to produce a sugar aldehyde derivative. The formed blue compound could be detected at $620 \mathrm{~nm}$, and the standard glucose solution could be color processed and quantified at the same time. When lactic acid was enzymatic, lactic acid was measured on the basis of the transfer of $\mathrm{H}^{+}$. Nitrotetrazolium blue chloride was reduced to purple by $\mathrm{H}^{+}$, which could be detected at $530 \mathrm{~nm}$. The above-mentioned two tests were realized by a commercial kit (Nanjing Jiancheng Biochemical Corporation, Nanjing, China). 


\subsubsection{Measurement of $\mathrm{pH}$}

The determination of drip loss refers to previous studies [25]. Muscle sample were cut into rectangular shapes with dimensions of $4 \times 1.5 \times 1.0 \mathrm{~cm}$ (length $\times$ width $\times$ thickness) for drip loss measurement. The cubed samples were weighed $\left(\mathrm{W}_{0}\right)$, wrapped, and suspended in a plastic jar; kept at $4{ }^{\circ} \mathrm{C}$ in the refrigerator for 2 days $(48 \mathrm{~h})$; and then re-measured $\left(\mathrm{W}_{1}\right)$. The reference value of drip loss of each sample $(\mathrm{W})$ was expressed as a percentage of weight loss from cut cube and calculated by the following equation:

$$
\mathrm{W}=\left(\mathrm{W}_{0}-\mathrm{W}_{1}\right) / \mathrm{W}_{0} \times 100 \%
$$

The $\mathrm{pH}$ value was measured using a portable $\mathrm{pH}$ metre Testo 205, (Lenzkirch, Germany). The average of three $\mathrm{pH}$ readings was averaged as the ultimate $\mathrm{pH}$ value for each cubed sample.

\subsubsection{Textural Parameters}

Texture parameters were measured in raw flesh immediately after removal of the second transversal steak of $1 \mathrm{~cm}$ thickness from fish. The assay was performed following the method described by Zhang [26] with minor modifications. Measurement was done by penetration of a probe perpendicularly to the cross-section of the $1 \mathrm{~cm}$ thick steak (in parallel to the muscle fibers). A texture analyzer TA. XT. Plus (Stable Micro Systems, Surrey, United Kingdom) equipped with a $25 \mathrm{~kg}$ load cell was used. The probe was a flat ended stainless-steel cylinder with a diameter of $36 \mathrm{~mm}$ and a pace of $1 \mathrm{~mm} / \mathrm{s}$. The texture profile curve of each sample was used to calculate the independent mechanical parameters (springiness, hardness, cohesiveness, and resilience).

\subsection{Statistical Analysis}

All data were subjected to using one-way analysis of variance (ANOVA); then, Duncan's multiple range test was used to identify the significant difference between treatments. All statistical analyses were performed with the Statistical Package SPSS 19.0 (IBM Corporation, Armonk, New York, USA 2010). All data were controlled in the same time period, and the differences between groups under different concentration conditions are analyzed. Standard deviation in each parameter and treatment was calculated and expressed as mean \pm SD. $p<0.05$ represented significant differences.

\section{Result}

\subsection{Biochemical Indicators and Antioxidant Capacity}

\subsubsection{Serum Biochemical Index}

At $12 \mathrm{~h}$ and $24 \mathrm{~h}$, the serum glucose levels of juvenile M. amblycephala exposed to $10 \mathrm{mg} / \mathrm{L}$ and $20 \mathrm{mg} / \mathrm{L}$ nitrite were significantly higher than the $1 \mathrm{mg} / \mathrm{L}$ and $5 \mathrm{mg} / \mathrm{L}$ experimental groups and the control group $(p<0.05)$. At $96 \mathrm{~h}$, the blood glucose levels of the $5 \mathrm{mg} / \mathrm{L}$ and $20 \mathrm{mg} / \mathrm{L}$ experimental groups were significantly higher than the $1 \mathrm{mg} / \mathrm{L}$ and $10 \mathrm{mg} / \mathrm{L}$ experimental groups and the control group (Figure 1a). At $12 \mathrm{~h}$, the serum cortisol level of the experimental groups was significantly higher than the control group, showing a significant positive correlation with the exposure concentration. Serum cortisol in the $20 \mathrm{mg} / \mathrm{L}$ experimental group was $321 \%$ higher than that in the control group. With the increase of exposure time, under the same nitrite exposure, the cortisol concentration of the experimental group began to decrease, and there was no significant difference in the cortisol concentration of each experimental group at $96 \mathrm{~h}$. (Figure $1 \mathrm{~b}$ ). 

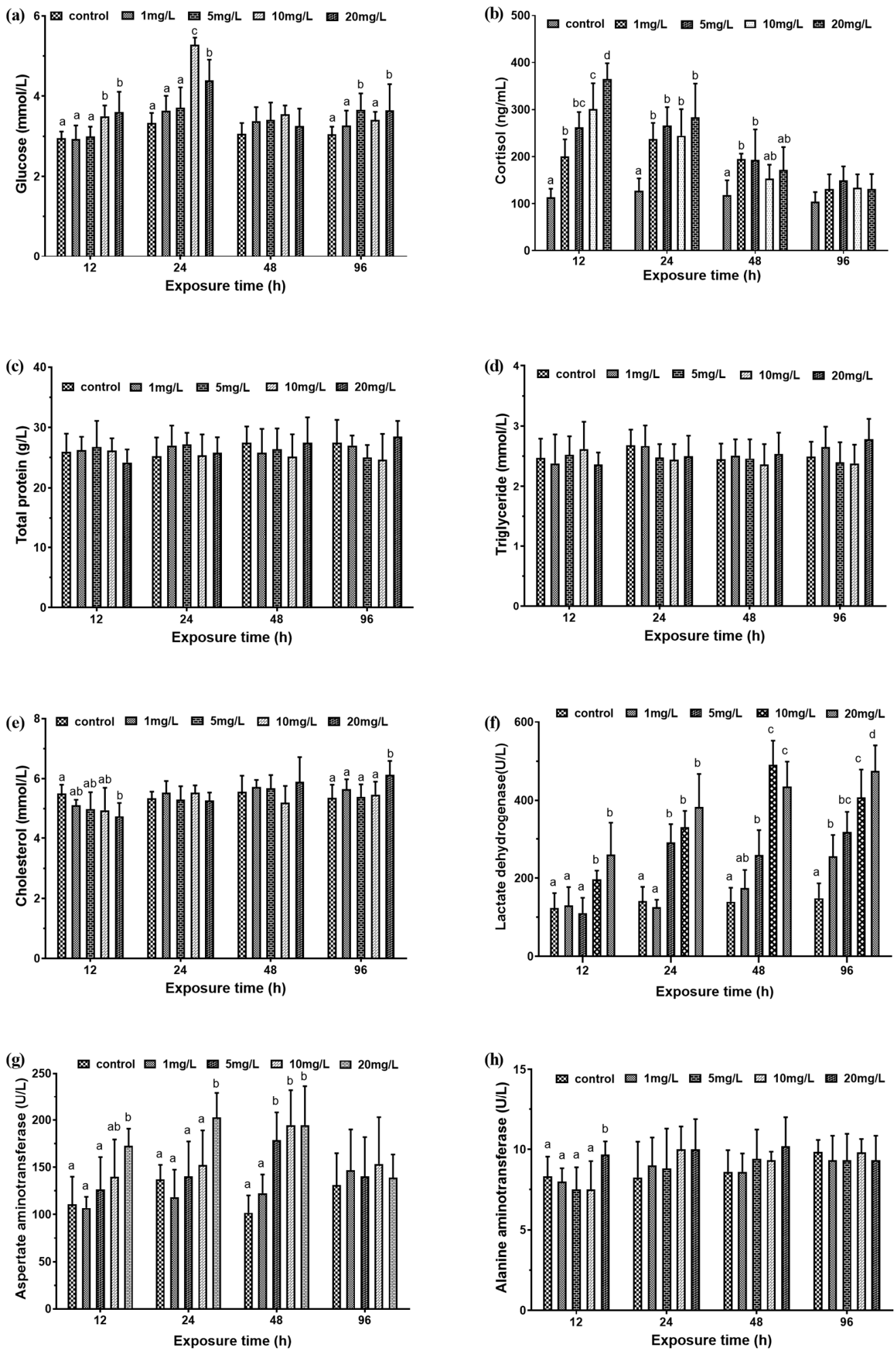

Figure 1. Serum biochemical index of $M$. amblycephala juveniles exposed to different nitrite concentration form $12 \mathrm{~h}$ to $96 \mathrm{~h}$. Data are expressed as mean $\pm \mathrm{SD}(\mathrm{n}=3)$. (a) Glucose concentration; (b) cortisol concentration; (c) total protein concentration; (d) triglyceride concentration; (e) total cholesterol concentration; (f) lactate dehydrogenase activity; (g) aspartate aminotransferase activity; (h) alanine aminotransferase activity. Different letters represent significant differences among treatments $(p<0.05)$ 
For experimental groups with different concentrations of nitrite, the total protein and serum triglyceride levels of $M$. amblycephala juveniles did not change significantly (Figure 1c,d). As for changes in total cholesterol concentration, at $12 \mathrm{~h}$, the total cholesterol concentration of the $20 \mathrm{mg} / \mathrm{L}$ experimental group was significantly lower than that of the control group. The value was $86 \%$ of the control group. As the exposure concentration increased, the total cholesterol concentration showed a gradual increase trend. At $96 \mathrm{~h}$, the total cholesterol concentration of the $20 \mathrm{mg} / \mathrm{L}$ experimental group was significantly higher than that of the other groups. The value was $114 \%$ of the control group (Figure 1e).

Among the experimental groups, the LDH activity showed an overall upward trend with the increase of exposure concentration. At $12 \mathrm{~h}$ and $48 \mathrm{~h}$, the LDH activity of the $10 \mathrm{mg} / \mathrm{L}$ and $20 \mathrm{mg} / \mathrm{L}$ experimental groups was significantly higher than the other groups. At $24 \mathrm{~h}$, there was significant difference in the LDH activity of the $5 \mathrm{mg} / \mathrm{L}, 10 \mathrm{mg} / \mathrm{L}$, and $20 \mathrm{mg} / \mathrm{L}$ experimental groups. At $96 \mathrm{~h}$, the LDH activity of the $20 \mathrm{mg} / \mathrm{L}$ experimental group was at its maximum (Figure 1f). The activity of AST in serum at $12 \mathrm{~h}, 24 \mathrm{~h}$, and $48 \mathrm{~h}$ increased with the increase of exposure concentration, but there was no significant difference between the exposure groups and the control group at $96 \mathrm{~h}$ (Figure 1g). At $12 \mathrm{~h}$, the activity of ALT concentration in $20 \mathrm{mg} / \mathrm{L}$ exposure group was significantly higher than that of the other groups $(p<0.05)$, and there were no significant differences at other times $(p>0.05)$ (Figure $1 \mathrm{~h})$.

\subsubsection{Liver Antioxidant Capacity}

At $12 \mathrm{~h}, 24 \mathrm{~h}$, and $96 \mathrm{~h}$, the T-AOC in the liver of bream was negatively relevance with the exposure concentration. At $48 \mathrm{~h}$, the T-AOC of the $10 \mathrm{mg} / \mathrm{L}$ experimental group was significantly greater than that of the other experimental groups and control group (Figure 2a). There was no significant difference in the SOD activity in the liver between the $10 \mathrm{mg} / \mathrm{L}$ experimental group and the control group at $24 \mathrm{~h}$ and $48 \mathrm{~h}(p>0.05)$. At $24 \mathrm{~h}$ and $48 \mathrm{~h}$, the SOD activity of $5 \mathrm{mg} / \mathrm{L}$ and $20 \mathrm{mg} / \mathrm{L}$ experimental groups were significantly higher than that of the control group $(p<0.05)$. At $24 \mathrm{~h}$, the SOD activity in the $1 \mathrm{mg} / \mathrm{L}$ experimental group was significantly higher than that in the control group $(p<0.05)$. However, at $48 \mathrm{~h}$, there was no significant difference between the results of the $1 \mathrm{mg} / \mathrm{L}$ experimental group and the control group $(p>0.05)$ (Figure $2 b$ ). For CAT, at $12 h, 24 h$, and $48 \mathrm{~h}$, as the exposure concentration increased, the activity of CAT gradually increased. At $96 \mathrm{~h}$, the CAT activity of the $1 \mathrm{mg} / \mathrm{L}$ and $20 \mathrm{mg} / \mathrm{L}$ experimental groups was significantly higher than that of the control group (Figure 2c). As for the GPx activity, there was no significant difference between the different exposure experimental groups (Figure 2d).

\subsection{Muscle Metabolism}

\subsubsection{Muscle Physiological Characteristics}

After exposure for $12 \mathrm{~h}, 24 \mathrm{~h}$, and $48 \mathrm{~h}$, the muscle glycogen concentration of the control group and $1 \mathrm{mg} / \mathrm{L}, 5 \mathrm{mg} / \mathrm{L}$, and $20 \mathrm{mg} / \mathrm{L}$ experimental groups were not significantly different, and the muscle glycogen concentration of the $10 \mathrm{mg} / \mathrm{L}$ experimental group was significantly lower than control group. However, at $48 \mathrm{~h}$, there was no significant difference in muscle glycogen concentration between the control group and the experimental groups (Figure 3a). At the same exposure time, there was no significant difference in the lactic acid concentration of the muscles of the control group and the experimental groups. However, with the increase of exposure time, the lactic acid concentration of muscle showed an increasing trend compared with that at $12 \mathrm{~h}$ (Figure $3 \mathrm{~b}$ ). 

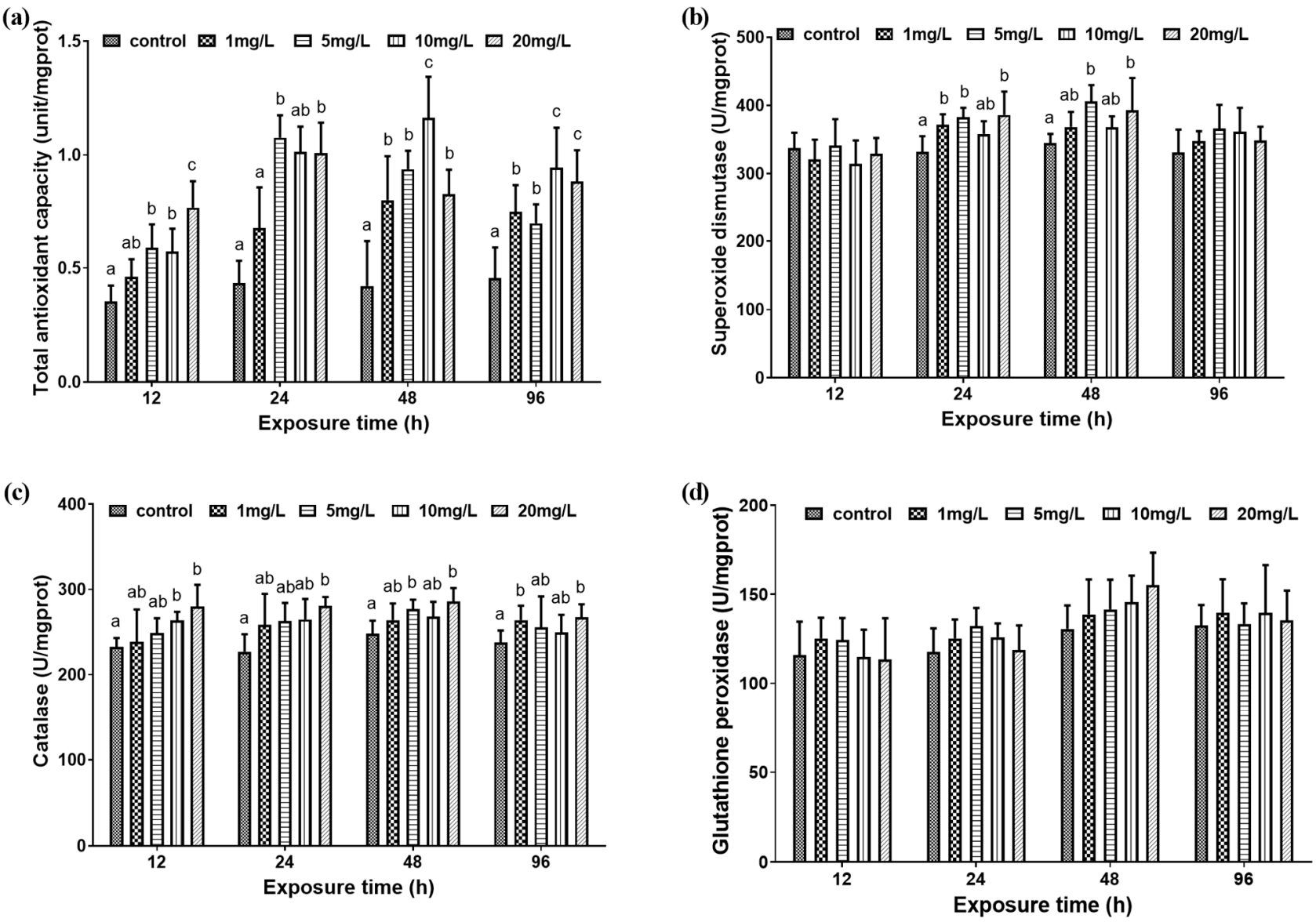

Figure 2. Liver antioxidant capacity of M. amblycephala juveniles exposed to different nitrite concentrations from $12 \mathrm{~h}$ to $96 \mathrm{~h}$. Data are expressed as mean $\pm \mathrm{SD}(\mathrm{n}=3)$. (a) Total antioxidant capacity value; (b) superoxide dismutase activity; (c) catalase activity; (d) glutathione peroxidase activity. Different letters represent significant differences among treatments $(p<0.05)$.
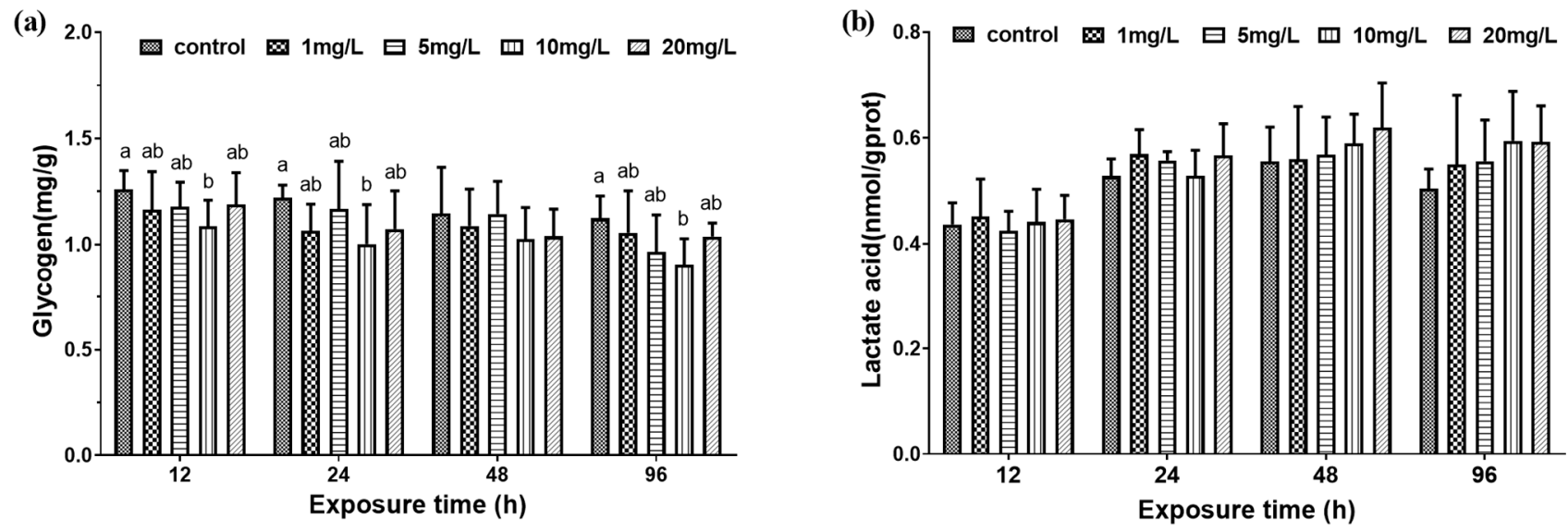

Figure 3. Concentration of muscle glycogen and lactate in M. amblycephala juveniles exposed to different nitrite concentrations from $12 \mathrm{~h}$ to $96 \mathrm{~h}$. Data are expressed as mean $\pm \operatorname{SD}(\mathrm{n}=3)$. (a) Muscle glycogen concentration; (b) lactic acid concentration. Different letters represent significant differences among treatments $(p<0.05)$.

Drip loss measured in the muscle samples of the experimental groups were not significantly different from that of the control group (Figure $4 \mathrm{a}$ ). At $12 \mathrm{~h}$, the $\mathrm{pH}$ value of the $10 \mathrm{mg} / \mathrm{L}$ experimental group was significantly higher than that of the control group, 
and the $\mathrm{pH}$ values of the other experimental groups were not significantly different from that of the control group. At $24 \mathrm{~h}, 48 \mathrm{~h}$, and $96 \mathrm{~h}$, there was no significant difference in $\mathrm{pH}$ value between the experimental groups and the control group (Figure $4 b$ ).
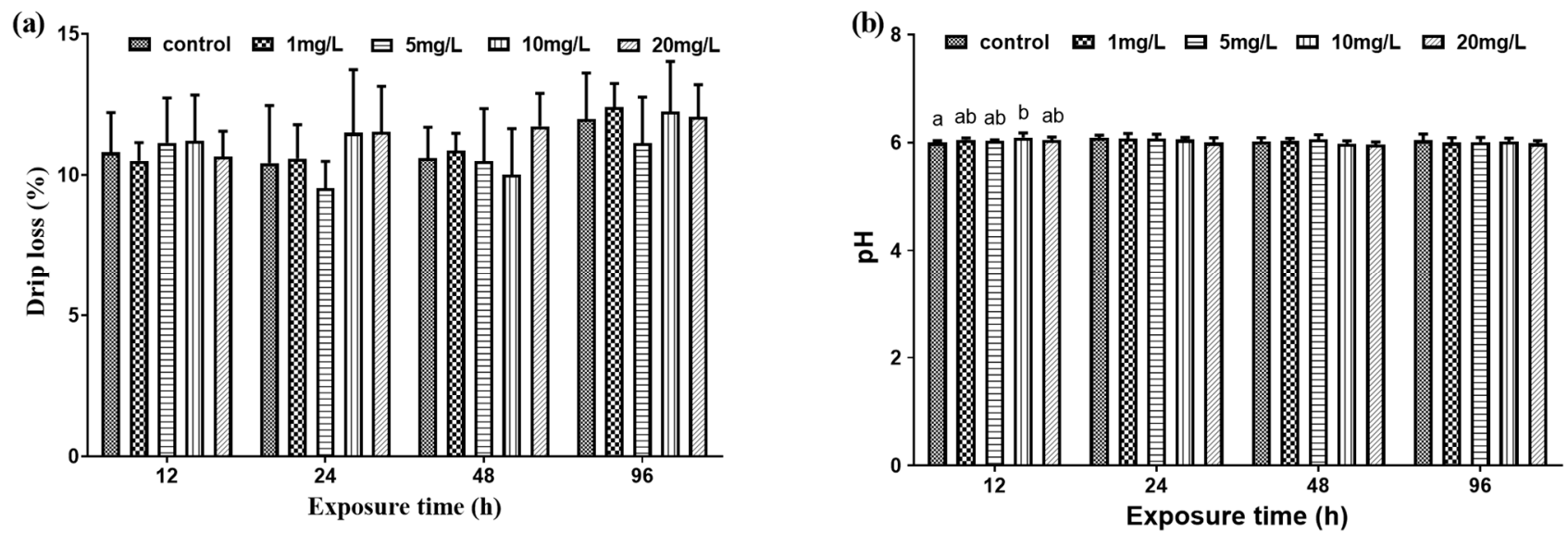

Figure 4. Drip loss (\%) and $\mathrm{pH}$ in $\mathrm{M}$. amblycephala juveniles exposed to different nitrite concentrations from $12 \mathrm{~h}$ to $96 \mathrm{~h}$. Data are expressed as mean \pm SD ( $\mathrm{n}=3)$. (a) Percentage of drip loss; (b) PH value. Different letters represent significant differences among treatments $(p<0.05)$.

\subsubsection{Muscle Physical Characteristics}

At $12 \mathrm{~h}$ and $96 \mathrm{~h}$, the hardness of the four experimental groups were significantly higher than that of the control group (Figure $5 \mathrm{a}$ ). At $12 \mathrm{~h}$, the springiness of the $10 \mathrm{mg} / \mathrm{L}$ and $20 \mathrm{mg} / \mathrm{L}$ experimental groups were significantly higher than that of the control group. At $24 \mathrm{~h}$ and $96 \mathrm{~h}$, the $10 \mathrm{mg} / \mathrm{L}$ experimental group had the maximum springiness. At $48 \mathrm{~h}$, there was no significant difference in elasticity between the experimental groups and the control group (Figure $5 b$ ). There was no significant difference in viscosity between the experimental groups and the control group (Figure 5c). At $12 \mathrm{~h}$ and $24 \mathrm{~h}$, the resilience of the $20 \mathrm{mg} / \mathrm{L}$ experimental group was significantly higher than that of the control group. At $48 \mathrm{~h}$, there was no significant difference in resilience between the experimental groups and the control group. At $96 \mathrm{~h}$, there was a positive correlation between resilience and exposure concentration (Figure 5d).
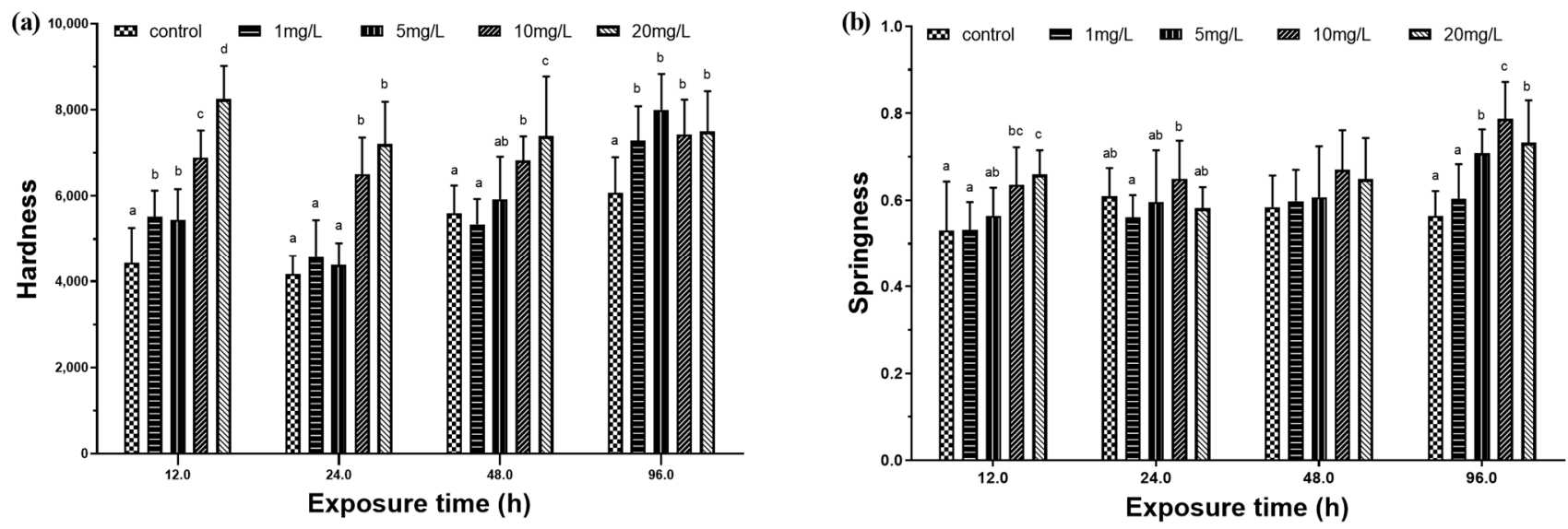

Figure 5. Cont. 

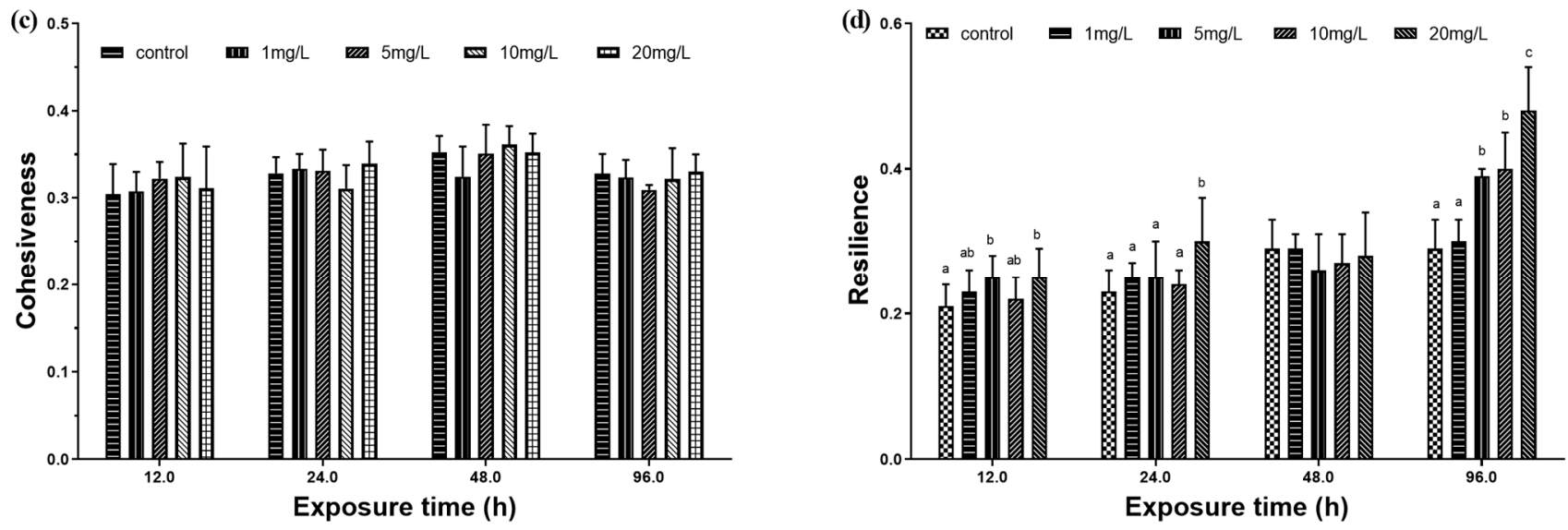

Figure 5. Muscle texture characteristics of M. amblycephala juveniles exposed to different nitrite concentrations from $12 \mathrm{~h}$ to $96 \mathrm{~h}$. Data are expressed as mean $\pm \mathrm{SD}(\mathrm{n}=3)$. (a) Hardness value; (b) springiness value; (c) cohesiveness value; (d) resilience value. Different letters represent significant differences among treatments $(p<0.05)$.

\section{Discussion}

\subsection{The Effect of Nitrite on Serum Biochemical Indices}

The triggering of fish anti-stress mechanism is mainly through the stress of fish regulating the central hypothalamus-pituitary-renal tissue axis (HPI), releasing adrenocorticotropic hormone (ACTH), and promoting stress hormones such as catecholamines and cortisol in the fish body [27]. The synthesis and release of the stress hormones induce stress response in the fish body, which can promote protein, fat, and carbohydrate metabolism by regulating various physiological and biochemical reaction processes of the body. In addition, as an oxidant, nitrite also triggers the activation of the protective effect of the fish body's antioxidant system, which triggers changes in the activity of enzymes including SOD, CAT, and GPx [18].

As a direct energy supply substance, blood glucose can maintain the internal environment stability under environmental stress and improve the energy security of osmotic regulation and material metabolism [28]. This experiment found that nitrite stress can lead to a significant increase in serum cortisol concentration. At $12 \mathrm{~h}$, the serum cortisol concentration and exposure concentration showed a significant positive correlation. The increase in cortisol concentration reduced the utilization of glucose by various tissues of the body, and at the same time enhanced the gluconeogenesis of the liver, resulting in an increase in blood glucose. Therefore, during the exposure period, the blood glucose concentration of $M$. amblycephala juveniles was observed to increase significantly in the higher concentration experimental group. Cholesterol and triglycerides are both important substances in fish lipid metabolism and play an important role in resisting external stress [29]. At $12 \mathrm{~h}$ exposure, the serum total cholesterol concentration decreased significantly with the increase of exposure concentration, while at $96 \mathrm{~h}$, the $20 \mathrm{mg} / \mathrm{L}$ experimental group increased significantly. That may mean excessive energy consumption during the initial resistance to external stress and that causes a decrease in cholesterol levels [30,31]. As time goes on, the fish metabolism compensation mechanism is activated, which makes the cholesterol level recover and rise again to resist stress [32,33].

In this experiment, the AST activity in the $20 \mathrm{mg} / \mathrm{L}$ experimental group was always higher than that of the control group at $12 \mathrm{~h}, 24 \mathrm{~h}$, and $48 \mathrm{~h}$ exposure, and had the maximum value. At $96 \mathrm{~h}$, there was no significant difference in AST activity between the experimental group and the control group. The results showed that nitrite stress may have a certain effect on the liver of M. amblycephala juveniles. $\mathrm{LDH}$ is the key enzyme to complete the anaerobic glycolysis process of glucose. The external stimuli would increase the lactic acid concentration of the fish body [34]. LDH can catalyze the degradation of lactic acid and maintain the body's internal environmental balance. Das [1] and other studies [35,36] 
found that the activity of serum LDH increased in Indian carp (Catla catla), South Asian wild carp (Labeo rohita), and Indian carp (Cirrhinus mrigala) in the $96 \mathrm{~h}$ exposure process, under the concentration exposure conditions $(1-1.8 \mathrm{mg} / \mathrm{L})$. In this study, it was found that at $24 \mathrm{~h}$, the activity of LDH in the blood of M. amblycephala juveniles increased significantly at $10 \mathrm{mg} / \mathrm{L}$ and $20 \mathrm{mg} / \mathrm{L}$, and as the exposure time increased, the LDH concentration in the low-concentration experimental groups also increased. It is positively correlated with exposure concentration. Therefore, acute nitrite stress may cause the accumulation of metabolic wastes in M. amblycephala juveniles.

\subsection{The Effect of Nitrite on Liver Antioxidant Capacity}

The function of the fish body's antioxidant system mainly depends on the changes in the activity of antioxidant enzymes. As the most important oxidase in the fish body, SOD plays an important role in the process of removing active oxygen, eliminating superoxide anion free radicals and protecting cells from temperature stress. Nitrite exposure can promote the formation of reactive oxygen species in aquatic animals, thereby inducing oxidative damage [37]. The increase of SOD, CAT, and GPx activity are considered to be a strategy for fish to cope with oxidative stress [38]. In this experiment, we also found that at $24 \mathrm{~h}$ and $48 \mathrm{~h}, \mathrm{SOD}$ activity in the liver of each experimental groups increased significantly to resist oxidative stress. CAT in organisms can reduce $\mathrm{H}_{2} \mathrm{O}_{2}$ in the body and maintain the normal physiological activities of cells and the body [39]. During the period of nitrite exposure, CAT activity also increased significantly with the increase of exposure concentration to resist the damage caused by oxidative stress. In addition, there are some other antioxidant enzymes such as GPx that can catalyze the degradation of hydrogen peroxide and hydroperoxide [40] and remove lipid peroxides [41]. Exposure to Macrobrachium nipponense with high concentration of sodium nitrite for $24 \mathrm{~h}$ will significantly reduce the GPx activity [42]. However, in this study, it was not found that nitrite had a significant effect on the GPx activity in M. amblycephala juveniles.

\subsection{The Effect of Nitrite on Muscle Quality}

Changes in concentration of lactic acid in the muscles are generally considered by two ways in nitrite stress. First, the inhibition of respiration causes increased lactic acid by anaerobic substrate oxidation to meet energy demand, as it has been found in silver catfish (Rhamdia quelen) [43]. At the same time, stress response involves metabolic activation and increased energy consumption. Glycogenolysis and gluconeogenesis are usually promoted under stress conditions, using amino acids and lactate as substrates [44]. In spite of this, the increase of lactic acid accumulation in muscle was not manifested in M. amblycephala juveniles exposed to nitrite. It suggested that anaerobic metabolism did little or no prevail in the present work.

A significant reduction in glycogen occurs in the $10 \mathrm{mg} / \mathrm{L}$ experimental group at $12 \mathrm{~h}, 24 \mathrm{~h}$, and $96 \mathrm{~h}$. Compared to the control group, other experimental groups showed a decline, but these were not significant. This indicated that nitrite could increase the metabolic consumption of glucose in the white muscle to resist stress. Acute exposure $(8 \mathrm{~h})$ to $20-30 \mathrm{mg} / \mathrm{L} \mathrm{NO}^{2-}$ also decreased glucose in white muscle and lactate in the muscle of Piaractus mesopotamicus [45] and Brycon amazonicus [2]. Muscle glycogen metabolism can be only exploited through the glycolytic pathway, but an increase in lactic acid levels was not observed. For $M$. amblycephala juveniles, nitrite stress may result in more muscle energy consumption rather than tissue hypoxia. Thus, only at $12 \mathrm{~h}$, the $\mathrm{pH}$ of the $10 \mathrm{mg} / \mathrm{L}$ experimental group was higher than that of the control group. As the exposure time increased, there was no significant difference between the experimental group and the control group in $\mathrm{pH}$.

Flesh quality is of increasing concern in the aquaculture industry with the increase of total production. Moreover, flesh quality is usually defined in terms of appearance, taste, smell, and nutritional composition. The quality of flesh is known to be influenced by 
extrinsic factors such as feeding regime, diet composition, and environment, which impact on structure and metabolic characteristics of muscle tissue [46].

With the value of drip loss or $\mathrm{pH}$, the quality of examined fillets could be possibly evaluated and determined in a simple and direct way [47]. Less drip loss always means loss of soluble protein and flavor compounds, leading to its flavor and mouthfeel being pronouncedly improved [48]. However, in this study, drip loss measured in muscle samples from different experimental groups showed no significant differences from the control group. For muscle $\mathrm{pH}$, a low ultimate muscle $\mathrm{pH}$ postmortem can lead to more rapid degradation of the muscle tissue [49]. In this study, only a lower $\mathrm{pH}$ was found in the control group in comparison to the experimental groups, suggesting a connection to a high glycogen level in the muscle [50]. The results also showed that it is possible to quickly adjust the $\mathrm{pH}$ conditions inside the fish muscle, and there was no significant difference at $24 \mathrm{~h}, 48 \mathrm{~h}$, and $96 \mathrm{~h}$.

Among the sensorial characteristics, texture is one of the most important parameters for fish producers, processors, and consumers. Nitrite stress significantly altered muscle hardness, springiness, and resilience. In this study, muscle hardness increased as exposure concentration gradually increased. With the prolonged exposure time, this trend had not changed significantly, and similar results were obtained on the springiness. This is consistent with the results of kuruma prawn (Penaeus japonicus) [51]. Moreover, muscle resilience significantly increased with the increase of exposure concentrations at $96 \mathrm{~h}$. For acute exposure, more exercise and higher consumption of energy metabolism in fish could possibly cause changes in muscle texture. These changes are also associated with glycogen concentration, which then influences muscle quality [52].

\section{Conclusions}

Acute exposure to nitrite in M. amblycephala juveniles could stimulate the HPI axis, promote the synthesis and release of stress hormones such as cortisol in the blood of the fish, intensify its metabolic activity, and cause excessive energy consumption. At the same time, the catabolism of energy substances in the liver and blood was intensified, and the gluconeogenesis was enhanced. It also damaged the tissues of M. amblycephala juveniles and induced the activation of the body's antioxidant system.

In short, acute nitrite stress could induce lower muscle glycogen concentration and increase metabolic enhancement and energy consumption of $M$. amblycephala juveniles. Meanwhile, the alteration of muscle texture properties eventually led to the muscle quality deterioration of M. amblycephala juveniles. Further research is needed for the exploration of muscle metabolism regulation mechanism which causes these changes.

Author Contributions: Conceptualization, C.Q. and R.T.; methodology, C.Q.; software, Z.H.; validation, Z.H., C.Q. and C.L.; formal analysis, Z.H.; investigation, C.Q. and C.L.; resources, R.T.; data curation, C.Q.; writing—original draft preparation, Z.H.; writing—review and editing, R.T.; visualization, R.T.; supervision, R.T.; project administration, R.T.; funding acquisition, R.T. All authors have read and agreed to the published version of the manuscript.

Funding: This research was funded by the National Key R\&D Program of China (No. 2019YFD0900301), China Agriculture Research System of MOF and MARA (CARS-45-24), and the National Natural Science Foundation (No. 31502140). The APC was funded by Rong Tang.

Institutional Review Board Statement: The animal study protocol was approved by Animal Experimental Ethical Inspection of Laboratory Animal Centre, Huazhong Agriculture University (ID number: HZAUFI-2020-0014).

Informed Consent Statement: Not applicable.

Data Availability Statement: The original contributions presented in the study are included in the article. Further inquiries can be directed to the corresponding author.

Acknowledgments: We thank Jean-Luc PROBST, Coral Chen and four anonymous reviewers for their very helpful and constructive comments that greatly improved the manuscript. 
Conflicts of Interest: The authors declare no conflict of interest.

\section{References}

1. Das, P.; Ayyappan, S.; Das, B.; Jena, J. Nitrite toxicity in Indian major carps: Sublethal effect on selected enzymes in fingerlings of Catla catla, Labeo rohita and Cirrhinus mrigala. Comp. Biochem. Physiol. Part C Toxicol. Pharmacol. 2004, 138, 3-10. [CrossRef] [PubMed]

2. Avilez, I.M.; de Aguiar, L.H.; Hori, T.S.; Moraes, G. Metabolic responses of matrinxã, Brycon Amazonicus (Spix \& Agassiz, 1829), exposed to environmental nitrite. Aquac. Res. 2012, 44, 596-603. [CrossRef]

3. Kim, J.-H.; Kang, J.-C. The lead accumulation and hematological findings in juvenile rock fish Sebastes Schlegelii exposed to the dietary lead (II) concentrations. Ecotoxicol. Environ. Saf. 2015, 115, 33-39. [CrossRef] [PubMed]

4. Kim, J.-S.; Ha, T.-Y.; Kim, S.; Lee, S.-J.; Ahn, J. Red paprika (Capsicum annuum L.) and its main carotenoid capsanthin ameliorate impaired lipid metabolism in the liver and adipose tissue of high-fat diet-induced obese mice. J. Funct. Foods 2017, 31, 131-140. [CrossRef]

5. Jensen, F.B. Nitrite disrupts multiple physiological functions in aquatic animals. Comp. Biochem. Physiol. Part A Mol. Integr. Physiol. 2003, 135, 9-24. [CrossRef]

6. Xian, J.-A.; Wang, A.-L.; Chen, X.-D.; Gou, N.-N.; Miao, Y.-T.; Liao, S.-A.; Ye, C.-X. Cytotoxicity of nitrite on haemocytes of the tiger shrimp, Penaeus Monodon, using flow cytometric analysis. Aquaculture 2011, 317, 240-244. [CrossRef]

7. Wang, J.; Tang, H.; Zhang, X.; Xue, X.; Zhu, X.; Chen, Y.; Yang, Z. Mitigation of nitrite toxicity by increased salinity is associated with multiple physiological responses: A case study using an economically important model species, the juvenile obscure puffer (Takifugu obscurus). Environ. Pollut. 2018, 232, 137-145. [CrossRef]

8. Chen, W.; Liu, H.; Zhang, Q.; Dai, S. Effect of nitrite on growth and microcystins production of Microcystis Aeruginosa PCC7806. Environ. Boil. Fishes 2010, 23, 665-671. [CrossRef]

9. Guo, H.; Xian, J.-A.; Wang, A.-L. Analysis of digital gene expression profiling in hemocytes of white shrimp Litopenaeus Vannamei under nitrite stress. Fish Shellfish. Immunol. 2016, 56, 1-11. [CrossRef] [PubMed]

10. Knudsen, P.K.; Jensen, F.B. Recovery from nitrite-induced methaemoglobinaemia and potassium balance disturbances in carp. Fish Physiol. Biochem. 1997, 16, 1-10. [CrossRef]

11. Ciji, A.; Sahu, N.P.; Pal, A.K.; Dasgupta, S.; Akhtar, M.S. Alterations in serum electrolytes, antioxidative enzymes and haematological parameters of Labeo Rohita on short-term exposure to sublethal dose of nitrite. Fish Physiol. Biochem. 2012, 38, 1355-1365. [CrossRef]

12. Lin, Y.; Miao, L.-H.; Pan, W.-J.; Huang, X.; Dengu, J.M.; Zhang, W.-X.; Ge, X.-P.; Liu, B.; Ren, M.-C.; Zhou, Q.-L.; et al. Effect of nitrite exposure on the antioxidant enzymes and glutathione system in the liver of bighead carp, Aristichthys nobilis. Fish Shellfish. Immunol. 2018, 76, 126-132. [CrossRef] [PubMed]

13. Das, P.C.; Ayyappan, S.; Jena, J.K.; Das, B.K. Effect of sub-lethal nitrite on selected haematological parameters in fingerling Catla Catla (Hamilton). Aquac. Res. 2004, 35, 874-880. [CrossRef]

14. da Costa, O.T.F.; Ferreira, D.J.D.S.; Mendonça, F.L.P.; Fernandes, M.N. Susceptibility of the Amazonian fish, Colossoma Macropomum (Serrasalminae), to short-term exposure to nitrite. Aquaculture 2004, 232, 627-636. [CrossRef]

15. Kim, J.-H.; Kim, J.-Y.; Lim, L.-J.; Kim, S.K.; Choi, H.S.; Hur, Y.B. Effects of waterborne nitrite on hematological parameters and stress indicators in olive flounders, Paralichthys Olivaceus, raised in bio-floc and seawater. Chemosphere 2018, 209, 28-34. [CrossRef] [PubMed]

16. Grosell, M.; Jensen, F. Uptake and effects of nitrite in the marine teleost fish Platichthys flesus. Aquat. Toxicol. 2000, 50, 97-107. [CrossRef]

17. Li, M.; Yu, N.; Qin, J.; Li, E.; Du, Z.; Chen, L. Effects of ammonia stress, dietary linseed oil and Edwardsiella Ictaluri challenge on juvenile darkbarbel catfish Pelteobagrus vachelli. Fish Shellfish. Immunol. 2014, 38, 158-165. [CrossRef]

18. Xie, L.; Chen, S.; Yao, C.; Li, D.; Li, L.; Tang, R. Nitrite induces endoplasmic reticulum stress and associates apoptosis of liver cells in grass carp (Ctenopharyngodon Idella). Aquaculture 2019, 507, 275-281. [CrossRef]

19. Kim, J.-H.; Kang, J.-C. The selenium accumulation and its effect on growth, and haematological parameters in red sea bream, Pagrus Major, exposed to waterborne selenium. Ecotoxicol. Environ. Saf. 2014, 104, 96-102. [CrossRef] [PubMed]

20. Sun, H.; Li, J.; Tang, L.; Yang, Z. Responses of crucian carp Carassius Auratus to long-term exposure to nitrite and low dissolved oxygen levels. Biochem. Syst. Ecol. 2012, 44, 224-232. [CrossRef]

21. Zhou, X.-X.; Wang, Y.-B.; Li, W.-F. Effect of feeding apidaecin on common carp (Cyprinus Carpio) growth performances and immune function. Aquaculture 2008, 279, 108-112. [CrossRef]

22. Martinez, C.B.; Souza, M.M. Acute effects of nitrite on ion regulation in two neotropical fish species. Comp. Biochem. Physiol. Part A Mol. Integr. Physiol. 2002, 133, 151-160. [CrossRef]

23. Das, P.; Ayyappan, S.; Jena, J.; Das, B. Nitrite toxicity in Cirrhinus Mrigala (Ham.): Acute toxicity and sub-lethal effect on selected haematological parameters. Aquaculture 2004, 235, 633-644. [CrossRef]

24. Hong, M.; Chen, L.; Sun, X.; Gu, S.; Zhang, L.; Chen, Y. Metabolic and immune responses in Chinese mitten-handed crab (Eriocheir Sinensis) juveniles exposed to elevated ambient ammonia. Comp. Biochem. Physiol. Part C Toxicol. Pharmacol. 2007, 145, 363-369. [CrossRef] [PubMed] 
25. Zhang, X.; Shen, Z.; Qi, T.; Xi, R.; Liang, X.; Li, L.; Tang, R.; Li, D. Slight increases in salinity improve muscle quality of grass carp (Ctenopharyngodon idellus). Fishes 2021, 6, 7. [CrossRef]

26. Zhang, X.; Wang, J.; Tang, R.; He, X.; Li, L.; Takagi, Y.; Li, D. Improvement of muscle quality of grass carp (Ctenopharyngodon Idellus) with a bio-floating bed in culture ponds. Front. Physiol. 2019, 10, 683. [CrossRef] [PubMed]

27. Guo, H.; Lin, W.; Wang, L.; Zhang, D.; Wu, X.; Li, L.; Li, D.; Tang, R.; Yang, L.; Qiu, Y. The supplementation of dietary selenium yeast and green tea-derived polyphenols improves antioxidant capacity and immune response in juvenile Wuchang bream under ammonia stress. Aquac. Res. 2020, 51, 3790-3803. [CrossRef]

28. Mommsen, T.P.; Vijayan, M.M.; Moon, T.W. Cortisol in teleosts: Dynamics, mechanisms of action, and metabolic regulation. Rev. Fish Biol. Fish. 1999, 9, 211-268. [CrossRef]

29. Montero, D.; Izquierdo, M.; Tort, L.; Robaina, L.; Vergara, J. High stocking density produces crowding stress altering some physiological and biochemical parameters in gilthead seabream, Sparus Aurata, juveniles. Fish Physiol. Biochem. 1999, 20, 53-60. [CrossRef]

30. Kumaraguru, A.; Beamish, F. Effect of permethrin (NRDC-143) on the bioenergetics of rainbow trout, Salmo gairdneri. Aquat. Toxicol. 1986, 9, 47-58. [CrossRef]

31. Cheng, S.-Y.; Shieh, L.-W.; Chen, J.-C. Changes in hemolymph oxyhemocyanin, acid-base balance, and electrolytes in Marsupenaeus japonicus under combined ammonia and nitrite stress. Aquat. Toxicol. 2013, 130, 132-138. [CrossRef]

32. Chen, J.-C.; Cheng, S.-Y. Hemolymph PCO2, hemocyanin, protein levels and urea excretions of Penaeus Monodon exposed to ambient ammonia. Aquat. Toxicol. 1993, 27, 281-291. [CrossRef]

33. Ciji, A.; Akhtar, M.S. Nitrite implications and its management strategies in aquaculture: A review. Rev. Aquac. 2019, 12, 878-908. [CrossRef]

34. Olsen, Y.A.; Einarsdottir, I.E.; Nilssen, K.J. Metomidate anaesthesia in Atlantic salmon, Salmo Salar, prevents plasma cortisol increase during stress. Aquaculture 1995, 134, 155-168. [CrossRef]

35. Das, P.C.; Ayyappan, S.; Jena, J.K.; Das, B.K. Acute toxicity of ammonia and its sub-lethal effects on selected haematological and enzymatic parameters of mrigal, Cirrhinus Mrigala (Hamilton). Aquac. Res. 2004, 35, 134-143. [CrossRef]

36. Bogin, E.; Marom, M.; Levi, Y. Changes in serum, liver and kidneys of cisplatin-treated rats; effects of antioxidants. Clin. Chem. Lab. Med. 1994, 32, 843-852. [CrossRef]

37. Sun, S.; Ge, X.; Zhu, J.; Xuan, F.; Jiang, X. Identification and mRNA expression of antioxidant enzyme genes associated with the oxidative stress response in the Wuchang bream (Megalobrama Amblycephala Yih) in response to acute nitrite exposure. Comp. Biochem. Physiol. Part C Toxicol. Pharmacol. 2014, 159, 69-77. [CrossRef]

38. Zheng, J.; Mao, Y.; Su, Y.; Wang, J. Effects of nitrite stress on mRNA expression of antioxidant enzymes, immune-related genes and apoptosis-related proteins in Marsupenaeus japonicus. Fish Shellfish. Immunol. 2016, 58, 239-252. [CrossRef]

39. Parihar, M.S.; Dubey, A.K.; Prakash, P. Responses of superoxide dismutase, glutathione peroxidase and reduced gluta-thione antioxidant defenses in gills of the freshwater catfish (Heteropneustes Fossills) to short-term elevated temperature. J. Therm. Biol. 1997, 22, 151-156. [CrossRef]

40. Wei, W.; Cuijuan, N.; Ying, G.; Li, L. The effects of environmental endocrine disruptors on fertilization and embryonic development of the fish Liza haematocheila. Comp. Biochem. Physiol. Part C 2008, 4, 466. [CrossRef]

41. Chatterjee, N.; Pal, A.; Manush, S.; Das, T.; Mukherjee, S. Thermal tolerance and oxygen consumption of Labeo Rohita and Cyprinus Carpio early fingerlings acclimated to three different temperatures. J. Therm. Biol. 2004, 29, 265-270. [CrossRef]

42. Wang, W.-N.; Wang, A.-L.; Zhang, Y.-J.; Li, Z.-H.; Wang, J.-X.; Sun, R.-Y. Effects of nitrite on lethal and immune response of Macrobrachium nipponense. Aquaculture 2004, 232, 679-686. [CrossRef]

43. de Lima, R.L.; Braun, N.; Kochhann, D.; Lazzari, R.; Neto, J.R.; Moraes, B.S.; Loro, V.L.; Baldisserotto, B. Survival, growth and metabolic parameters of silver catfish, Rhamdia Quelen, juveniles exposed to different waterborne nitrite levels. Neotrop. Ichthyol. 2011, 9, 147-152. [CrossRef]

44. Hemre, G.-I.; Mommsen, T.; Krogdahl, Å. Carbohydrates in fish nutrition: Effects on growth, glucose metabolism and hepatic enzymes. Aquac. Nutr. 2002, 8, 175-194. [CrossRef]

45. Neyrão, I.M.; Biller, J.D.; Takahashi, L.S.; Urbinati, E.C. Modulation of immunity and hepatic antioxidant defense by corticosteroids in pacu (Piaractus Mesopotamicus). Comp. Biochem. Physiol. Part A Mol. Integr. Physiol. 2021, 260, 111025. [CrossRef] [PubMed]

46. Johnston, A.I. Muscle development and growth: Potential implications for flesh quality in fish. Aquaculture 1999, 177, 99-115. [CrossRef]

47. He, H.-J.; Wu, D.; Sun, D.-W. Rapid and non-destructive determination of drip loss and pH distribution in farmed Atlantic salmon (Salmo Salar) fillets using visible and near-infrared (Vis-NIR) hyperspectral imaging. Food Chem. 2014, 156, 394-401. [CrossRef] [PubMed]

48. Luciano, G.; Monahan, F.; Vasta, V.; Biondi, L.; Lanza, M.; Priolo, A. Dietary tannins improve lamb meat colour stability. Meat Sci. 2009, 81, 120-125. [CrossRef]

49. Ofstad, R.; Egelandsdal, B.; Kidman, S.; Myklebust, R.; Olsen, R.L.; Hermansson, A.-M. liquid loss as effected by post mortem ultrastructural changes in fish muscle: Cod (Gadus Morhua L) and salmon (Salmo Salar). J. Sci. Food Agric. 1996, 71, 301-312. [CrossRef]

50. Wang, P.A.; Vang, B.; Pedersen, A.M.; Martinez, I.; Olsen, R.L. Post-Mortem degradation of myosin heavy chain in intact fish muscle: Effects of $\mathrm{pH}$ and enzyme inhibitors. Food Chem. 2011, 124, 1090-1095. [CrossRef] 
51. Ando, M.; Nakamura, H.; Harada, R.; Yamane, A. Effect of super chilling storage on maintenance of freshness of Kuruma Prawn. Food Sci. Technol. Res. 2004, 10, 25-31. [CrossRef]

52. Suárez, M.; Martínez, T.; Abellán, E.; Arizcun, M.; Jimenez, M.C.H.; Hidalgo, M.; Cardenete, G. The effects of the diet on flesh quality of farmed dentex (Dentex Dentex). Aquaculture 2009, 288, 106-113. [CrossRef] 